\section{Hybrid Analogues of Gramicidin S and Gratisin}

\author{
MAKOTO TAMAKI \\ Department of Chemistry, Faculty of Science, Toho University, \\ 2-2-1 Miyama, Funabashi, Chiba 274-8510, Japan \\ (Received for publication February 16, 2004)
}

Gramicidin S (GS), cyclo(-Val-Orn-Leu-D-Phe-Pro- $)_{2}{ }^{1,2)}$, and Gratisin (GR), cyclo(-Val-Orn-Leu-D-Phe-Pro-DTyr- $)_{2}^{3 \sim 9),}{ }^{\dagger}$ are potent cyclopeptide antibiotics and adopt an antiparallel $\beta$-sheet conformation ${ }^{10 \sim 12)}$ (Fig. 1). In the studies of the structure-activity relationship of these antibiotics, the mode of action has been proposed that when these antibiotics interact with a cell membrane of target microorganisms, they adopt antiparallel $\beta$-sheet conformations with $\mathrm{C}_{2}$ symmetry and results in disruption of its cell membrane. ${ }^{1 \sim 9.13)}$ In addition, no resistance has been found for the antibiotics, because it requires significant alteration of the lipid composition of the cell membrane. ${ }^{14)}$ In view of the fact that widespread antibiotic resistance has become a serious threat to public health ${ }^{15 \sim 18)}$, these amphiphilic antibiotics are attractive targets for new drug discovery.

In these studies, we would like to report the design and synthesis of a new hybrid analogue, cyclo(-Val-Orn-Leu-DPhe-Pro-Val-Orn-Leu-D-Phe-Pro-D-Tyr-) (7a), containing both the sequences of the (GS) pentapeptide (-Val-OrnLeu-D-Phe-Pro-) and the (GR) hexapeptide (-Val-Orn-LeuD-Phe-Pro-D-Tyr-) in the molecule (Fig. 1). The antiparallel $\beta$-sheet conformations of GS and GR place the charged Orn side chains on one side of the plane of the molecule and the hydrophobic Val and Leu side chains on the other side, and this plays an important role for exhibiting high antibiotic activity. ${ }^{2)}$ If each conformation of the partial sequences in the GS and GR molecules held in the hybrid analogue (7a), 7a may possess the side-chain arrangement required for exhibiting the activity of GS and GR, even though 7a is not $C_{2}$ symmetric. Further, we synthesized the two cycloundecapeptides, cyclo(-Val-Orn-Leu-D-Phe-ProVal-Orn-Leu-D-Phe-D-Tyr-Pro-) (7b) and cyclo(-Val-OrnLeu-D-Phe-Pro-Val-Orn-Leu-Pro-D-Phe-D-Tyr-) (7c), which are hybrids of GS and two GR peptides possessing the high antibiotic activity, cyclo(-Val-Orn-Leu-D-Phe-D-Tyr-Pro-) ${ }_{2}$ (GR2) and cyclo(-Val-Orn-Leu-Pro-D-Phe-D-Tyr- $)_{2}$ (GR3), respectively (Fig. 1 ).

The synthesis of peptide 7a was performed by a conventional liquid phase method. (Fig. 2) Boc-D-Tyr $\left(\mathrm{BzlCl}_{2}\right.$ )-ValOrn(Z)-Leu-D-Phe-Pro-OBzl (1a) ${ }^{\dagger \dagger}$ and Boc-Val-Orn(Z)Leu-D-Phe-Pro-OBzl (2a) were synthesized from Pro benzyl ester by step-by-step elongation using 1-ethyl-3-(3-dimethyl aminopropyl) carbodiimide hydrochloride (EDCI) and 1-hydroxybenzotriazole, and then saponified to give Bochexapeptide (3a) and Boc-pentapeptide (4a). Compound 3a was converted into the corresponding succinimide ester $\left(\mathbf{3 a}^{\prime}\right)$ with EDCI and $N$-hydroxysuccinimide (HONSu).

Fig. 1. Primary structure of gramicidin S (GS), gratisin peptides (GR, GR2, and GR3) and its hybrid analogous $(\mathbf{7 a} \sim 7 \mathbf{c})$.

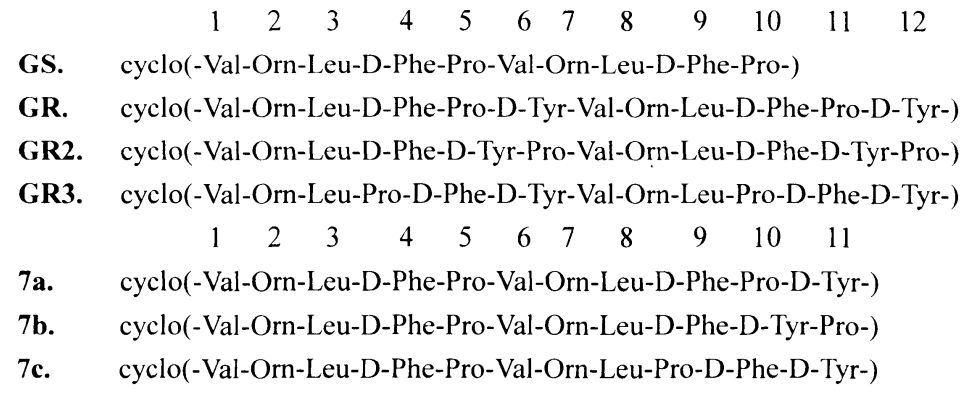

* Corresponding author: tamaki@chem.sci.toho-u.ac.jp

$\dagger$ Amino acid residues with no prefix are of L-configuration. The abbreviations of amino acids and peptides are in accordance with the rules of IUPAC-IBU commission of Biological Nomenclature.

${ }^{\dagger+}$ Abbreviations used are as follows: Boc, $t$-butoxycarbonyl; Z, benzyloxycarbonyl; OBzl, Benzyloxy; BzlCl, 2 , 6 -dichlorobenzyl. 
Fig. 2. Synthetic scheme of cyclo(-Val-Orn-Leu-D-Phe-Pro-Val-Orn-Leu-D-Phe-Pro-D-Tyr-) (7a).

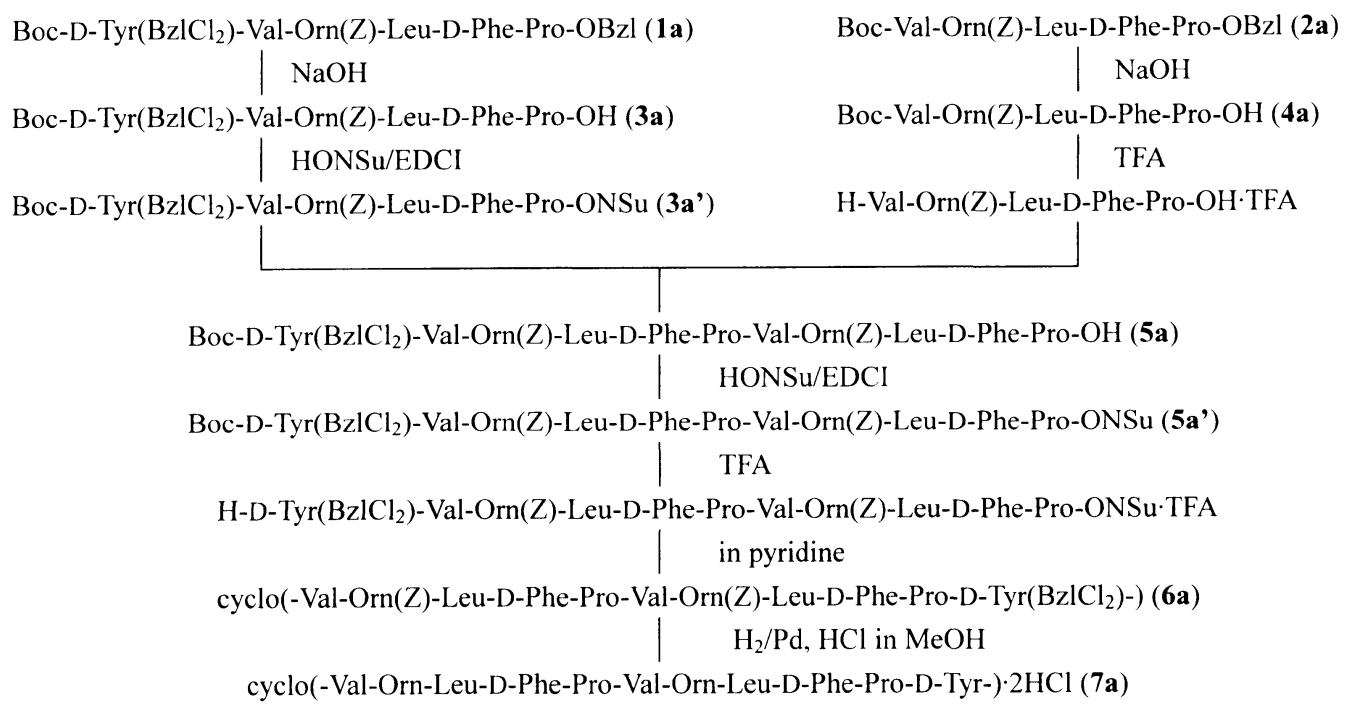

Table 1. Yields and analytical data of intermediary products of hybrid analogs $7 \mathbf{a} \sim 7 \mathbf{c}$.

\begin{tabular}{|c|c|c|c|c|}
\hline & $\begin{array}{l}\text { yield } \\
(\%)\end{array}$ & $\begin{array}{l}\mathrm{mp} \\
\left({ }^{\circ} \mathrm{C}\right)\end{array}$ & $\begin{array}{l}{[\alpha]_{D}^{25}\left({ }^{\circ}\right)} \\
(c 0.5, \mathrm{DMF})\end{array}$ & Formula $(\mathrm{MW})^{\mathrm{a})}$ \\
\hline $\begin{array}{l}\text { 2c. Boc-D-Phe-D-Tyr }\left(\mathrm{BzlCl}_{2}\right) \text {-Val-Orn(Z)- } \\
\text { Leu-D-Phe-Pro-OBzl }\end{array}$ & 51 & $215-216$ & -13.5 & $\mathrm{C}_{75} \mathrm{H}_{91} \mathrm{O}_{13} \mathrm{~N}_{8} \mathrm{Cl}_{2} \cdot 0.5 \mathrm{H}_{2} \mathrm{O}$ \\
\hline $\begin{array}{l}\text { 4c. Boc-D-Phe-D-Tyr }\left(\mathrm{BzlCl}_{2}\right) \text {-Val-Om(Z)- } \\
\text { Leu-D-Phe-Pro-OH }\end{array}$ & 90 & $198-200$ & -12.6 & $\mathrm{C}_{68} \mathrm{H}_{85} \mathrm{O}_{13} \mathrm{~N}_{8} \mathrm{Cl}_{2} \cdot 0.5 \mathrm{H}_{2} \mathrm{O}$ \\
\hline $\begin{array}{l}\left.\text { 5a. Boc-D-Tyr(BzlCl }{ }_{2}\right) \text {-Val-Orn(Z)-Leu-D-Phe- } \\
\text { Pro-Val-Orn(Z)-Leu-D-Phe-Pro-OH }\end{array}$ & 55 & $190-194$ & $\begin{array}{l}-37.3 \\
\text { (c } 1)\end{array}$ & $\mathrm{C}_{97} \mathrm{H}_{128} \mathrm{O}_{20} \mathrm{~N}_{13} \mathrm{Cl}_{2} \cdot 2.5 \mathrm{H}_{2} \mathrm{O}(1896.1)$ \\
\hline $\begin{array}{l}\text { 5b. Boc-Val-Orn(Z)-Leu-D-Phe-D-Tyr }\left(\mathrm{BzlCl}_{2}\right) \text { - } \\
\text { Pro-Val-Orn(Z)-Leu-D-Phe-Pro-OH }\end{array}$ & 94 & $148-149$ & $\begin{array}{r}-37.8 \\
\text { (c } 1)\end{array}$ & $\mathrm{C}_{97} \mathrm{H}_{128} \mathrm{O}_{20} \mathrm{~N}_{13} \mathrm{Cl}_{2} \cdot 1.5 \mathrm{H}_{2} \mathrm{O}(1878.1)$ \\
\hline $\begin{array}{l}\text { 5c. Boc-Val-Orn(Z)-Leu-Pro-D-Phe-D-Tyr }\left(\mathrm{BzlCl}_{2}\right) \text { - } \\
\text { Val-Orn(Z)-Leu-D-Phe-Pro-OH }\end{array}$ & 95 & 162 & -16.5 & $\mathrm{C}_{97} \mathrm{H}_{128} \mathrm{O}_{20} \mathrm{~N}_{13} \mathrm{Cl}_{2} \cdot 2 \mathrm{H}_{2} \mathrm{O} \quad(1887.1)$ \\
\hline $\begin{array}{l}\left.\text { 6a. cyclo[-D-Tyr(BzlCl }{ }_{2}\right) \text {-Val-Orn(Z)-Leu-D-Phe- } \\
\text { Pro-Val-Orn(Z)-Leu-D-Phe-Pro-] }\end{array}$ & 35 & $237-240$ & -110.3 & $\mathrm{C}_{92} \mathrm{H}_{118} \mathrm{O}_{16} \mathrm{~N}_{13} \mathrm{Cl}_{2} \cdot 2.5 \mathrm{H}_{2} \mathrm{O}(1778.0)$ \\
\hline $\begin{array}{l}\text { 6b. cyclo[-Val-Orn(Z)-Leu-D-Phe-D-Tyr }\left(\mathrm{BzlCl}_{2}\right) \text { - } \\
\text { Pro-Val-Orn(Z)-Leu-D-Phe-Pro-] }\end{array}$ & 45 & $231-233$ & -61.2 & $\mathrm{C}_{92} \mathrm{H}_{118} \mathrm{O}_{16} \mathrm{~N}_{13} \mathrm{Cl}_{2} \cdot 4 \mathrm{H}_{2} \mathrm{O} \quad(1805.0)$ \\
\hline $\begin{array}{l}\text { 6c. cyclo[-Val-Orn(Z)-Leu-Pro-D-Phe- } \\
\text { D-Tyr }\left(\mathrm{BzlCl}_{2}\right) \text {-Val-Orn(Z)-Leu-D-Phe-Pro-] }\end{array}$ & 37 & $\begin{array}{l}220 \\
\text { (decomp.) }\end{array}$ & $\begin{array}{l}-42.5 \\
(\mathrm{c} 0.3)\end{array}$ & $\mathrm{C}_{92} \mathrm{H}_{118} \mathrm{O}_{16} \mathrm{~N}_{13} \mathrm{Cl}_{2} \cdot 2 \mathrm{H}_{2} \mathrm{O} \quad(1769.0)$ \\
\hline
\end{tabular}

a) The results of elemental analysis agreed with calculated values within $\pm 0.3 \%$.

b) Boc-D-Tyr( $\mathrm{BzlCl}_{2}$ )-Val-Orn(Z)-Leu-D-Phe-Pro-OBzl (1a), . Boc-D-Tyr( $\left.\mathrm{BzlCl}_{2}\right)$-Val-Orn(Z)-Leu-D-Phe-Pro-OH (3a), Boc-Val-Orn(Z)-Leu-D-Phe-Pro-OBzl (2a and 2b), Boc-Val-Orn(Z)-Leu-D-Phe-Pro-OH (4a and 4b), Boc-Val-Orn(Z)-Leu-D-Phe-D-Tyr(BzlCl 2 )-Pro-OBzl (1b), and Boc-Val-Orn(Z)-Leu-D-Phe-D-Tyr(BzlCl $\left.{ }_{2}\right)$-Pro-OH (3b), have been reported in the literature. ${ }^{7.20)}$ 
Table 2. Yields and analytical data of hybrid analogs $7 \mathbf{a} \sim 7 \mathbf{c}$.

7a. cyclo(-Val-Orn-Leu-D-Phe-Pro-D-Tyr-Val-Orn-Leu-D-Phe-Pro-)-2HCl yield, $65 \%$; mp $248-2500^{\circ} \mathrm{C}$ (decomp.) ; $[\alpha]_{\mathrm{D}}{ }^{25}-172.0^{\circ}$ (c 0.5 , EtOH). MS (FAB), m/z $1304\left(\mathrm{C}_{69} \mathrm{H}_{102} \mathrm{O}_{12} \mathrm{~N}_{13} ; \mathrm{M}+\mathrm{H}^{+}\right)$.

Amino acid analysis : Val, 2.20 ; Orn, 2.10 ; Leu, 2.20 ; Phe, 2.10 ; Pro, 1.92 ; Tyr, 1.00 Found: $\mathrm{C}, 55.49 ; \mathrm{H}, 7.58 ; \mathrm{N}, 12.30 \%$. Calcd for $\mathrm{C}_{69} \mathrm{H}_{102} \mathrm{O}_{12} \mathrm{~N}_{13} \cdot 2 \mathrm{HCl} \cdot 6.5 \mathrm{H}_{2} \mathrm{O}$

C, $55.41 ; \mathrm{H}, 7.88 ; \mathrm{N}, 12.17 \%$.

7b. cyclo(-Val-Orn-Leu-D-Phe-D-Tyr-Pro-Val-Orn-Leu-D-Phe-Pro-)·2HCl yield, $90 \%$; mp $228-2311^{\circ} \mathrm{C}$ (decomp.) ; $[\alpha]_{\mathrm{D}}{ }^{25}-164.2^{\circ}$ (c 0.5 , EtOH). MS (FAB), m/z $1304\left(\mathrm{C}_{69} \mathrm{H}_{102} \mathrm{O}_{12} \mathrm{~N}_{13} ; \mathrm{M}+\mathrm{H}^{+}\right)$.

Amino acid analysis : Val, 1.96 ; Orn, 1.90 ; Leu, 2.08 ; Phe, 2.04 ; Pro, 2.06 ; Tyr, 1.00 Found: $\mathrm{C}, 55.88 ; \mathrm{H}, 7.57 ; \mathrm{N}, 12.23 \%$. Calcd for $\mathrm{C}_{69} \mathrm{H}_{102} \mathrm{O}_{12} \mathrm{~N}_{13} \cdot 2 \mathrm{HCl} \cdot 6 \mathrm{H}_{2} \mathrm{O}$ :

C, $55.75 ; \mathrm{H}, 7.86 ; \mathrm{N}, 12.25 \%$.

7c. cyclo(-Val-Orn-Leu-Pro-D-Phe-D-Tyr-Val-Orn-Leu-D-Phe-Pro-)-2HCl

yield, $99 \%$; mp $225^{\circ} \mathrm{C}$ (decomp.); $[\alpha]_{\mathrm{D}}{ }^{25}-131.0^{\circ}$ (c $\left.0.5, \mathrm{EtOH}\right)$.

MS (FAB), m/z $1304\left(\mathrm{C}_{69} \mathrm{H}_{102} \mathrm{O}_{12} \mathrm{~N}_{13} ; \mathrm{M}+\mathrm{H}^{+}\right)$.

Amino acid analysis : Val, 2.10 ; Orn, 2.00 ; Leu, 2.20 ; Phe, 2.10 ; Pro, 1.90 ; Tyr, 1.00 Found: C, $57.72 ; \mathrm{H}, 7.87 ; \mathrm{N}, 12.63 \%$. Calcd for $\mathrm{C}_{69} \mathrm{H}_{102} \mathrm{O}_{12} \mathrm{~N}_{13} \cdot 2 \mathrm{HCl} \cdot 3.5 \mathrm{H}_{2} \mathrm{O}$ : C, $57.45 ; \mathrm{H}, 7.82 ; \mathrm{N}, 12.62 \%$.

Table 3. Antibiotic activities of $\mathbf{G S}$ and hybrid peptides $\mathbf{7 a} \sim \mathbf{7 c}$.

\begin{tabular}{|c|c|c|c|c|}
\hline \multirow[b]{2}{*}{ Test organisms } & \multicolumn{4}{|c|}{ Minimum inhibitory concentration $(\mu \mathrm{g} / \mathrm{ml})^{\text {a) }}$} \\
\hline & GS & $7 \mathbf{a}$ & $7 \mathbf{b}$ & $7 c$ \\
\hline S. aureus Smith & 3.13 & 3.13 & 3.13 & 6.25 \\
\hline S. aureus MS353 AO & 3.13 & 3.13 & 3.13 & 6.25 \\
\hline S. aureus 0175 & 3.13 & 6.25 & 3.13 & 6.25 \\
\hline S. epidermidis ATCC 27626 & 3.13 & 3.13 & 3.13 & 6.25 \\
\hline S. pyogenes N.Y.5 & 3.13 & 3.13 & 3.13 & 3.13 \\
\hline S. pyogenes S-23 & 3.13 & 3.13 & 6.25 & 3.13 \\
\hline S. agalactiae ATCC 12386 & 3.13 & 3.13 & 3.13 & 6.25 \\
\hline M. luteus ATCC 9341 & 3.13 & 6.25 & 12.5 & 6.25 \\
\hline B. subtilis ATCC 6633 & 3.13 & 3.13 & 3.13 & 3.13 \\
\hline E. coli $\mathrm{NIHJ}-\mathrm{JC} 2$ & $>100$ & $>100$ & $>100$ & $>100$ \\
\hline K. pneumoniae NCTC 9632 & 12.5 & 25 & $>100$ & $>100$ \\
\hline P. aeruginosa PA01 & $>100$ & $>100$ & $>100$ & $>100$ \\
\hline
\end{tabular}

a) Minimum inhibitory concentration $(\mu \mathrm{g} / \mathrm{ml})$ was determined by an agar dilution method with $10^{6}$ organisms per milliliter. 
Coupling of $\mathbf{3} \mathbf{a}^{\prime}$ with pentapeptide derived from $\mathbf{4 a}$ afforded the undecapeptide (5a), which was converted into the undecapeptide succinimide ester $\left(\mathbf{5} \mathbf{a}^{\prime}\right)$. Boc-group of $\mathbf{5} \mathbf{a}^{\prime}$ was removed by the action of trifluoroacetic acid (TFA), and then the succinimide ester was cyclized under high dilution (peptide concentration: $3 \times 10^{-3} \mathrm{M}$ ) in pyridine at $45^{\circ} \mathrm{C}$ for 3 hours. The resulting product was purified by means of high-performance liquid chromatography, followed by recrystallization. The cycloundecapeptide (6a) was obtained in $35 \%$ yield. The removal of all the masking groups of $6 \mathbf{a}$ by hydrogenolysis yielded $7 \mathbf{a}$. Peptides $7 \mathbf{b}$ and 7c were synthesized in a similar manner, in 45 and $37 \%$ cyclization yields, respectively. The homogeneity of hybrid analogs $7 \mathbf{a} \sim \mathbf{7} \mathbf{c}$ was confirmed by means of thin-layer chromatography, amino acid analysis, HPLC, elemental analysis, and FAB mass spectrometry (Table 1 and 2).

The antibiotic activity of these hybrid analogues $7 \mathbf{a} \sim 7 \mathbf{c}$ and GS is summarized in Table 3. The hybrid analogue 7a showed antibiotic activity against all Gram-positive microorganisms tested, and its activity is the same activity as that of GS. Other hybrid analogues $7 \mathbf{b}$ and $7 \mathbf{c}$ also showed strong activity. These results suggest that a secondary structure having the side-chain arrangement required for the antibiotic activity is present in these hybrid analogues, despite the fact that their primary structure is not $\mathrm{C}_{2}$ symmetric.

To investigate the structure-activity relationship of these hybrid analogues, CD spectra of GS, GR peptides and the three hybrid analogues, $7 \mathbf{a} \sim 7 \mathbf{c}$, were measured in aqueous solutions (Fig. 3). The shapes of the CD spectra of $7 \mathbf{a} \sim 7 \mathbf{c}$ are similar to the graphical average of the CD spectra of the GS and GR peptides, but the trough of the CD curves is slightly shallower than their graphical averages. The difference found in the ellipticities of these compounds seems to reflect the difference of the stability of their structures in aqueous solutions. We reported that the CD spectra of the GS and GR peptides reflect the ring features near the Pro residue, but not always the entire structure of the molecule. ${ }^{7.19)}$ The existence of additivity in CD spectra suggests that these hybrid analogs have both conformations around the $\beta$-turn part of the GS and GR peptides, in other words, structures with the side-chain arrangement required for exhibiting the activity of GS and GR peptides.

Further detailed conformational analysis of these hybrid peptides are needed in order to clearly understand the structure-activity relationship.

\section{Acknowledgments}

I thank to the staff of the Research Laboratories of Asahi Chemical Industry Co. for their elemental analysis, microbiological assays, and the measurement of the FAB mass.

\section{References}

1) BAttersby, A. R. \& L. C. Craig: The molecular weight

Fig. 3. CD spectra of GS, GR peptides and its hybrid analogs $7 \mathbf{a} \sim 7 \mathbf{c}$ in aqueous solution.

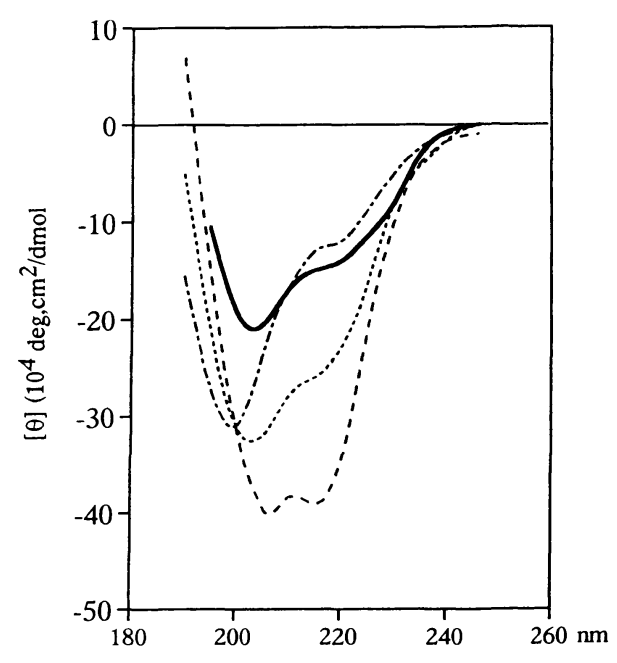

[A]

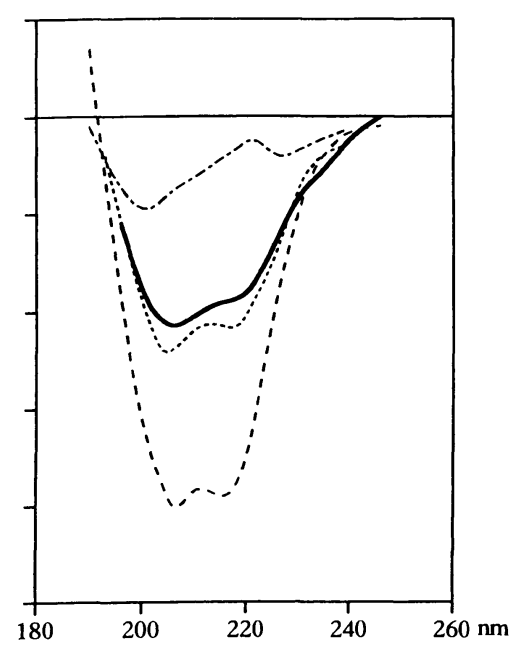

[B]

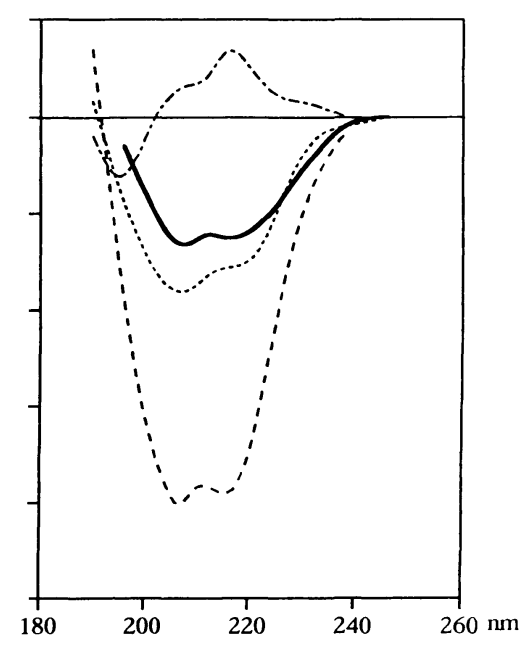

[C]

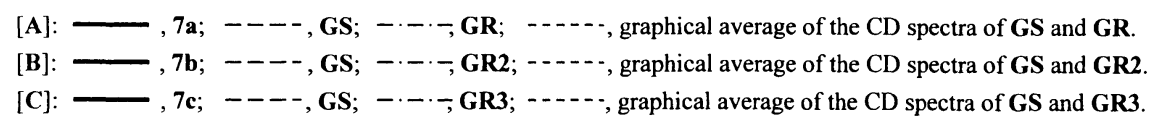


determination of polypeptides. J. Am. Chem. Soc. 73: 1887 1888, 1951

2) Izumiya, N.; T. Kato, H. Aoyagi, M. Waki \& M. Kondo: "Synthetic Aspects of Biologically Active Cyclic Peptide-Gramicidin S and Tyrocidines", Kodansha, Tokyo, and Halsted press, New York, 1979

3) Zharikova, G. G.; S .P. Myaskovskaya \& A. B. Silaev: Antibiotic gratisin derived from the cells of the mutant Bacillus brevis strain Y-33. Vestn. Mosk. Univ. Biol. Pochvoved. 27: 110 112, 1972

4) Myaskovskaya, S. P.; G. G. Zharikova \& A. B. Silaev: Amino acid composition and some of the physicochemical properties of gratisin. Vestn. Mosk. Univ. Biol. Pochvoved. 28: 123 125, 1973

5) Tamaki, M.; M. Takimoto, S. Sofuku \& I. Muramatsu: Synthetic studies on gratisin. J. Antibiotics 34: 1227 1228, 1981

6) Tamaki, M.; M. Takimoto, S. Sofuku \& I. Muramatsu: Synthetic studies on gratisin II. J. Antibiotics 36: $751 \sim 752,1983$

7) TAMAKI, M.: Studies on peptide antibiotic "gratisin". Bull. Chem. Soc. Jpn. 57: 3210 3220, 1982

8) Tamaki, M.; M. Takimoto \& I. Muramatsu: Studies of a peptide antibiotic "gratisin" II. Bull. Chem. Soc. Jpn. 60: $2101 \sim 2104,1987$

9) Tamaki, M.; M. Takimoto, S. Nozaki \& I. Muramatsu: Adsorption of cyclic peptides analogous to gramicidin $\mathrm{S}$ and gratisin onto octadecylsilica stationary phase and bacteria cells. J. Chromatogr. 413: 287 292, 1987

10) Hodgkin, D. C. \& B. M. Oughton: Possible molecular models for gramicidin $\mathrm{S}$ and their relationship to present ideas of protein structure. Biochem. J. 65: 752 756, 1957

11) Stern, A.; W. A. Gibbons \& L. C. Craig: A conformational analysis of gramicidin $\mathrm{S} \sim \mathrm{A}$ by nuclear magnetic resonance. Proc. Natl. Acad. Sci. USA 61: $734 \sim 741,1968$
12) OhNishi, M. \& D. W. URRY: Temperature dependence of amide proton chemical shifts: The secondary structures of gramicidin $\mathrm{S}$ and valinomycin. Biochim. Biophys. Res. Commun. 36: 194 202, 1969

13) Prenner, E. J.; R. N. A. H. Lewis \& R. N. McElhaney: The interaction of the antimicrobial peptide gramicidin $\mathrm{S}$ with lipid bilayer model and biological membranes. Biochem. Biophys. Acta 1462: 201 221, 1999

14) Hancock, R. E. W.: Peptide antibiotics. The Lancet 349 : 418 422, 1997

15) Travis. J.: As the development of antibiotic-resistant bacteria accelerated, research on new antibiotics lags. But a few promising lines of investigation remain open. Science 264: 360 362, 1994

16) Kohli, R. M.; C. T. Walsh \& M. D. Burkart: Biomimetic synthesis and optimization of cyclic antibiotics. Nature 418: 658 661, 2002

17) BU, X.; X. Wu, G. XIE \& Z. GuO: Synthesisi of tyrocidine $A$ and its analogues by spontaneous cyclization in aqueous solution. Org. Lett. 4: 2893 2895, 2002

18) Wu, X.; X. Bu, K. M. Wong, W. Yan \& Z. Guo: Biomimetic syntheisis of gramicidin $\mathrm{S}$ and analougues by enzymatic cyclization of linear precursors on solid support. Org. Lett. 5: 1749 1752, 2003

19) Tamaki, M.; T. Okitsu, M. Araki, H. Sakamoto, M. TAKimoto \& I. Muramatsu: Synthesis and properties of gramicidin $\mathrm{S}$ analogs containing D-Phe-PRO-L-D-Val or LPhe-L-Pro-D-Val sequences in place of D-Phe-L-Pro-L-Val sequence in the $\beta$-turn part of the antibiotic. Bull. Chem. Soc. Jpn. 58: $531 \sim 535,1985$

20) Tamaki, M.; T. Okitsu, M. Araki, H. Sakamoto, M. TAKIMOTO \& I. MURAMATSU: CD spectra and cyclization of linear pentapeptides as gramicidin S precursors with a benzyloxycarbonyl group on the side chain of ORN residue. Bull. Chem. Soc. Jpn. 66: 3113 3115, 1993 